\title{
Elulood Läti etniliste kultuuride uurimises: liivlaste ja mustlaste lood
}

\author{
Ieva Garda-Rozenberga, Māra Zirnīte
}

\begin{abstract}
Teesid: Artiklis käsitletakse liivlaste ja Läti mustlaste pärimusliku ajaloo intervjuusid, mille salvestused asuvad Läti Rahvusliku Suulise (Pärimusliku) Ajaloo Arhiivis Riias. Helisalvestused on tehtud 1980. aastate lõpust alates, suurem osa mustlaste lugusid on talletatud 2013. aastal alanud Läti etnilis-kultuuriliste vähemusrühmade uurimisprojekti raames. Intervjuuanalüüsis lähtutakse ühelt poolt biograafilise intervjuuga seonduvatest teooriatest, teisalt intertekstuaalsuse kontseptsioonist. Esile tuuakse jutustaja teemavalikud ja jutustamise stiil, ent seda kuulaja - lätlasest intervjueerija vaatepunktist. Nii keskendutakse intervjuumeetodi dialoogilisele loomusele, aga ka kultuuride omavahelistele seostele.
\end{abstract}

Märksõnad: elulugu, etnilis-kultuurilised kogukonnad, liivlased, mustlased, suuline ajalugu / pärimuslik ajalugu

Antropoloogide väitel on jutustamine universaalne oskus: maailmas ei ole kultuure ega ühiskondi, kus lugusid ei jutustataks (Riessmann 1993; Myerhoff 1980). Samas ei kasutata jutustamisel (sh ka eluloo jutustamisel) üht ja üldtuntud mudelit. Järgnevas artiklis käsitleme elulugusid, mille jutustajad esindavad küll erinevaid etnilis-kultuurilisi kogukondi, kuid neid seob ühine elukoht - Läti, ja nad on pikemat aega olnud seotud läti kultuurikeskkonnaga. ${ }^{1}$ Uurimuse üldraamiks on küsimus, kuidas elulugudes avaldub Lätis elavate etnilis-kultuuriliste rühmade eripära ja omavaheline sidusus.

Elulugudes on kultuurisidusalt ühendatud individuaalsus ja üldised tavad, ümbrus, sotsiaalne keskkond, kokkupuuted teiste kultuuridega. Antropoloog Edward M. Bruner rõhutab erinevust tegelikkuse (elatud elu, kogemuste) ja jutustatu vahel (Bruner 1986: 5-7; vt ka Bauman 1986: 5, 11-12; Skultans 1998: 17-26; Bela-Krūmin̦a 2002). Siinses eluloovaatluses eeldame, et elulood lähtuvad kogemusest. Sellest tulenevalt küsime, millise ettekujutuse võib lugude kaudu saada kogemusest ja jutuks olevast tegelikkusest. Eluloo kui teksti mõistmisel lähtume kommunikatsiooniprotsessile omasest intertekstuaalsusest (Bauman \& Briggs 1990: 59). Intertekstuaalsust on rakendatud küll pigem 
kirjalike tekstide uurimiseks, kuid see sobitub ka elulugude uurimisele, sest suuline kommunikatsioon on uurijatele pakkunud üha uusi impulsse süüvida vahetus suhtluses loodud tekstide eripärasse: n-ö lahutada neid osadeks, dekonstrueerida ja panna uuesti kokku. Ka suuliselt esitatud elulugudes, nagu kogemusele tuginevates lugudes üldiselt või tekstides, mida Erving Goffman (1959) on nimetanud enese-esitluseks (presentation of self), leidub sarnasusi, millest tulenevalt võib intertekstuaalsust pidada tunnuslikuks mitte ainult kirjanduslikele või rahvaluuletekstidele. Näiteks Richard Bauman, viidates Mihhail Bahtinile, selgitab, kuidas suulise kommunikatsiooni uurimine haakub varasema kirjandusteadusliku intertekstuaalsuse uurimisega: ka suulises suhtlussituatsioonis on ilmne nähtus, mida Mihhail Bahtin iseloomustab kui paratamatut viibimist "võoraste sõnade maailmas", kuhu tuleb paigutada ka enda sõnalised väljendused (Bauman 2004: 4-6; vrd Bahtin 1986: 60-102).

Siinses artiklis tutvustame elulugusid, mida jutustasid liivlaste ja mustlaste esindajad Lätis suulise (pärimusliku) ajaloo uurijatele. Analüüsitavad intervjuud on tallel Rahvusliku Suulise (Pärimusliku) Ajaloo Arhiivis. ${ }^{2}$

Viimase kahekümne aasta jooksul on sellesse arhiivi kogunenud mahukas liivi pärimusliku ajaloo helisalvestuste kogu. Mälestused on jäädvustatud läti

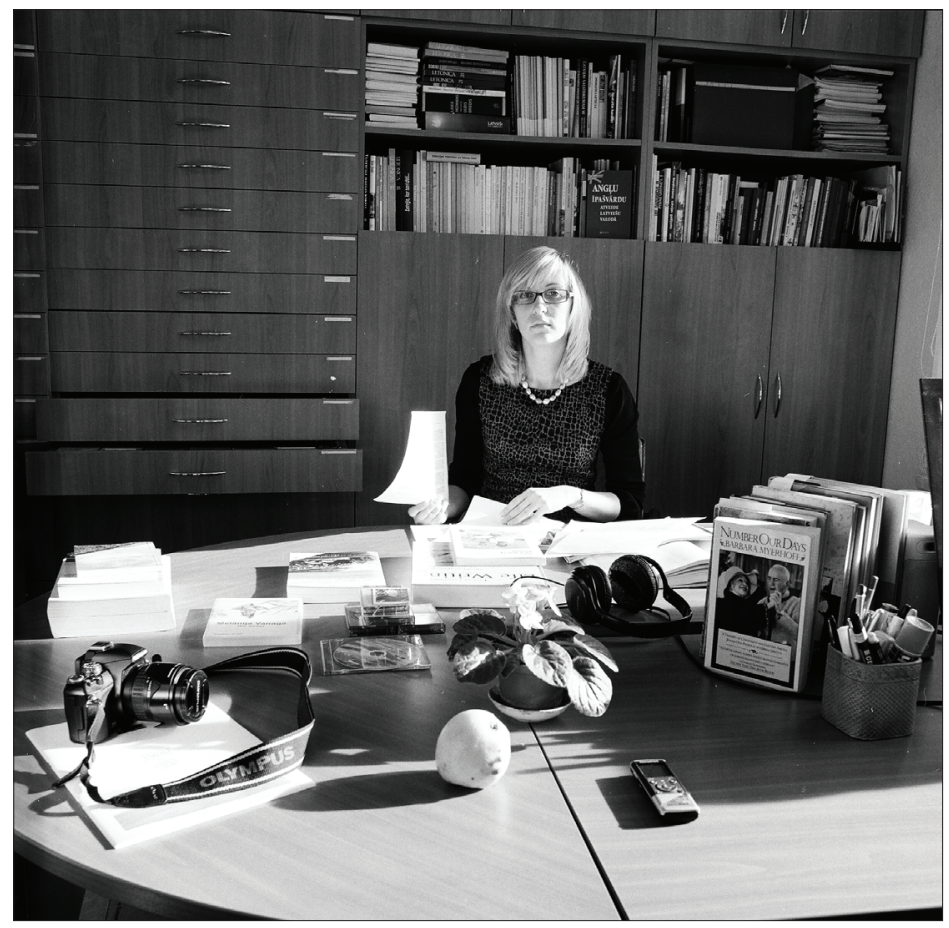

Ieva Garda-Rozenberga Rahvusliku Suulise Ajaloo arhiivis Riias. Māra Brašmane foto 2012. 
Maija Krūmina Rahvusliku Suulise Ajaloo arhiivis Riias. Māra Brašmane foto 2012.
Ieva Garda-Rozenberga ja Maija Krūmina Rahvusliku Suulise Ajaloo arhiivis Riias. Māra Brašmane foto 2012.
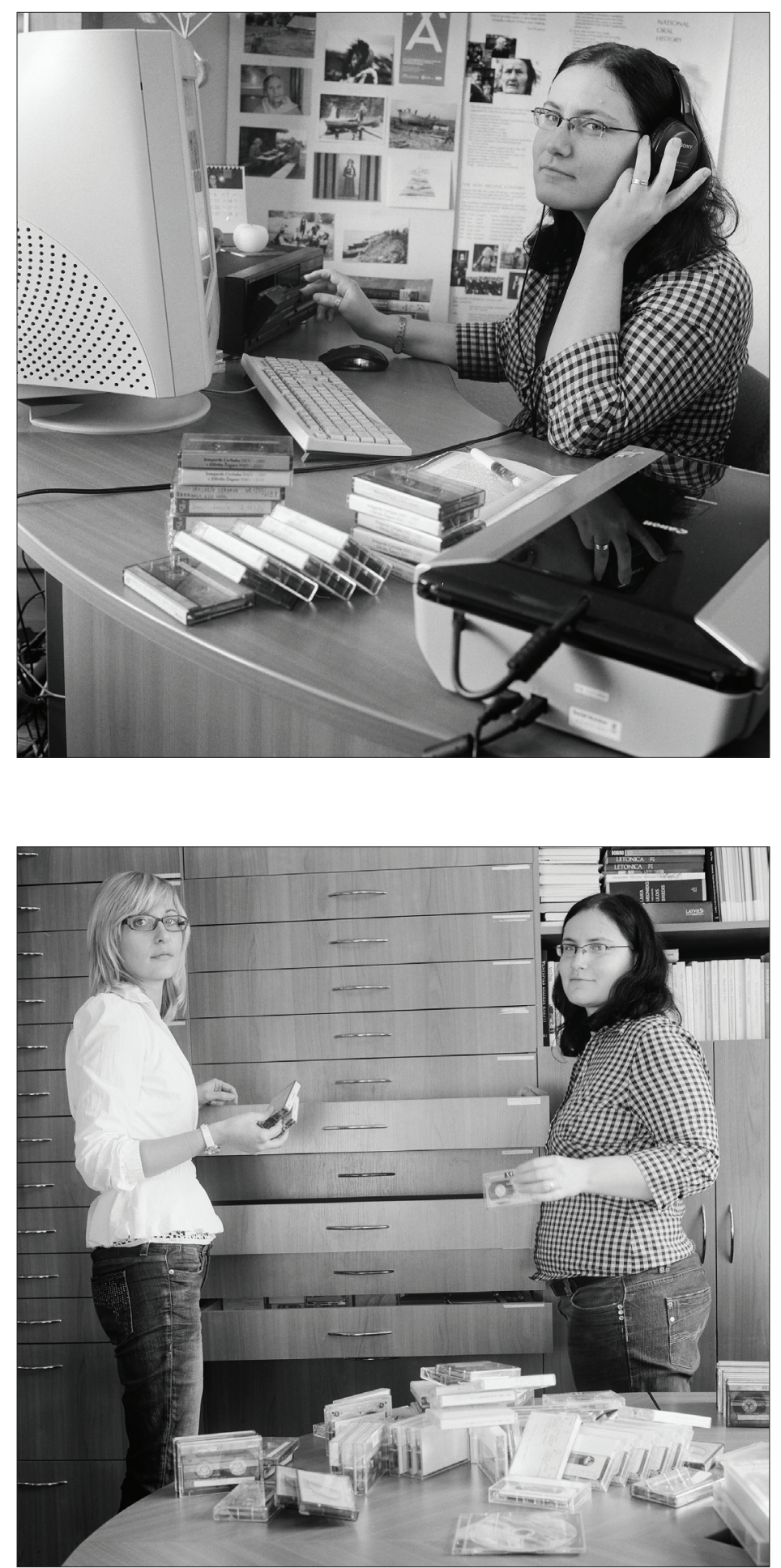
keeles, sest intervjueerijad olid läti keele rääkijad. Täpsemalt on helilindil läti keele üks dialekte, sest suurem osa Põhja-Kuramaa rannas sündinud ja kasvanud liivlasi räägivad läti keele liivipärast murret. Intervjueerimise ajal oskasid liivi keelt veel vaid üksikud jutustajad. Intervjuud mustlastega on samuti dokumenteeritud läti keeles. Osa neist on tehtud 1990. aastatel, kuid suurem osa on salvestatud 2013. aasta suvel seoses vastava uurimisprojekti käivitumisega. Kuramaal elavad mustlased kõnelevad (nagu liivlasedki) enamasti läti keele liivipärast murret. Isekeskis kasutavad mustlased aga oma keelt ehk selle kohalikku, näiteks Kuramaa murret.

Elulugudel on nii mustlaste kui ka liivlaste etnose ajaloo ja sotsiaalse mälu uurimises oluline koht, sest nii mustlaste kui ka liivlaste kultuur on peamiselt suuline. Seetõttu on iga katse rekonstrueerida kummagi rahva ajalugu mitte ainult raskendatud, vaid ka keeruline, sest suulisi teateid annab mitmeti interpreteerida. Interpretatsiooni mõjutab muu hulgas uurimisobjekti eripära, nagu antud juhul näiteks eluloo-žanr. Elulood on ainulaadsed, teatavas sotsiaalses olukorras loodud esitused, mis tuginevad küll tõsielule, kuid mida mõjutavad nii intervjuu kontekst, jutustaja kui ka intervjueerija isiksus, jutustamis- ja kuulamisoskus, samuti individuaalne looming. Seega on eluloo loomine vaadeldav sotsiaalse toiminguna teatud ajas ja ruumis. Kuid rõhutada tuleb, et tegemist on ühtlasi ka kultuurikogemuse ühe vormiga, millel on pikema-aegne tähendus ja funktsioon, ja et konkreetse esituse käigus loodav ainulaadne tekst on intertekstuaalselt siiski seotud ka nende tekstidega, mis on loodud varasemate esituste käigus (Gilman 2009; Bauman 2004: 4; Bauman \& Briggs 1990: 73).

Elulugude eripära on tingitud mälust ja selle selektiivsest iseloomust, mida mõjutab nii ajalõhe kõnesolevate sündmuste ja jutustamise vahel kui ka ühiskonna väärtushoiakute ja normide muutumine, samuti sündmuste meenutamise sagedus ning neile erinevatel eluperioodidel omistatud tähendus (Krūmiṇa 2012: 27). Jutustades lugu oma elust viitab jutustaja mitte ainult toimunud sündmustele, vaid ta esitab kõnesoleva üldisemas kultuurilises, ühiskondlikus ja isiklikus kontekstis. Ka jutustuse struktuur - valitud episoodid, loo ülesehitus, keelelised ja teised suhtlusviisid kannavad teavet kultuuri ja ühiskonna kohta, milles jutustaja on elanud ja elab.

Järgnevas kahes alalõigus vaatleme, kuidas kumbki siinkäsitletav etniliskultuuriline rühm mõistab ja näitab oma minevikku. Me ei keskendu niivõrd minevikusündmustele, kuivõrd nende esitusele. Osutame sellele, kuidas minevikuvaade avaldub nii jutustuse ülesehituses kui ka stiilis (kujutluspiltide loomes ja väljendusvahendite kasutamises) ning intertekstuaalsuses. Nii koondub tähelepanu jutus ilmnevatele aspektidele, mis viitavad jutustajate tavapärasele keskkonnale, traditsioonilisele eluviisile, aga ka pärimusele ning ajastu ja läti kultuuri mõjule. 


\section{Kuulates liivlaste jutte}

Pärimusliku ajaloo uurijad leidsid 20. sajandi lõpul liivlaste kogukonnas andekaid jutustajaid. Suurem osa neist oli sündinud 20. sajandi alguses, nii et nad mäletasid ühist ja samas eraklikku elulaadi sajandialguse liivi kalurikülades. Lapsepõlve muljed püsisid, kuigi ümbrus aja jooksul muutus - sünnikoht ja esivanemate tavad hoidsid ikka oma võimuses ja lubasid jutustustes esile manada kunagisi vaatepilte, mis nüüd on läinud liivi kultuurilukku.

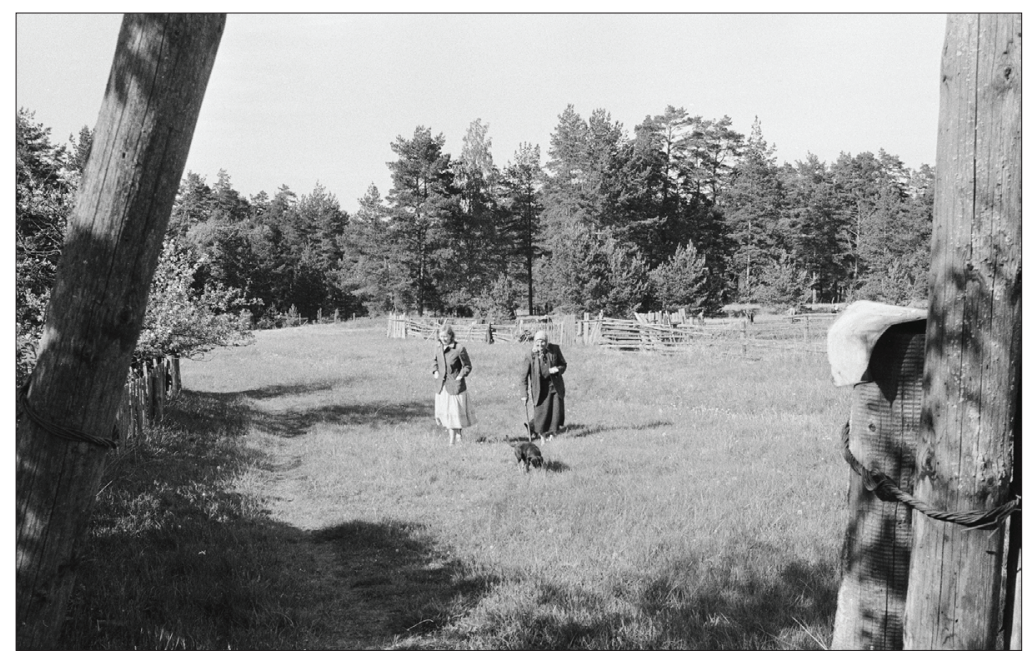

Māra Zirnīte ja Lizete Švanenberga, Lūžnā. Vaira Strautniece foto 1987.

Kultuur on seotud kindla taustaga: aeg ja ruum, traditsioonid, rahvajutud ja -laulud, uskumused ja muidugi keel, milles see kõik elustub. Liivi kultuuri sõnum on neis lugudes aga kuulatav läti keeles. Liivi kultuuri valdajad küll mäletasid oma lapsepõlve kodust keelt, kuid suurem osa neist seda enam ei rääkinud. Vestluskaaslaste puududes keel hääbus. Et seda osa liivi kultuurist vahendatakse läti keele kaudu, on üks aja märke, mis iseloomustab liivi kultuuri tänapäeval. Kuigi liivi kultuur jätkub akadeemilises keskkonnas, seda on võimalik õppida, pole see ometi enam suhtluskeel. Samas esineb läti keeles liivi keelest laenatud sõnu ja grammatilisi vorme, mis on samuti üks liivi kultuuri jätkumise vorme tänapäeval.

Järgnevalt tsiteeritud katkendid on võetud intervjuudest Kuramaa endiste kalurikülade elanike ja nende järglastega (vt ka Zirnīte 2011). Valikus lähtusime 
lugudes esil olevatest teemadest ja sündmustest - need kirjeldavad peamiselt elu liivi kultuuri keskkonnas. Valitud näidetes on peamine mitte kõnesolevate faktide täpsus, vaid kujutluspildi väljendusrikkus. Igas jutus on oma tundekeel, mis annab märku inimvaimu aktiivsest kohalolust nii elus kui mälestustele tuginevas jutustuses. Lugude võrdlusest koorub välja see, mida liivi elukeskkonna kirjeldamisel loomulikuks ja endastmõistetavaks peeti. Järeldub, et liivlased alustasid 20. sajandit veel ühtse kogukonnana, kus jätkusid põlvkondade vältel välja kujunenud traditsioonid, elulaad, töövõtted ja kus ringlesid muistendid, jutustati edasi esivanemate mälestusi. Seda teadmata on tänapäeva liivi rannas reisija kaotaja, sest metsad, sood, metsistunud külakohad enamasti vaikivad. Kuid roheline mets, valge liiv ja sinine meri pole liivlaste lipuvärvideks valitud juhuslikult. Nii nägid oma randa merelt tagasi tulles kalurid. See oli liivlaste maailm, kus kajastusid inimeste sammud. Nii laulis sellest omal ajal ka Blūmi koor Îral (Lielirbes), mida koori laulja Emīlija Rulle oma intervjuus meenutab. Laulus küsitakse: "Kas tahad teada, mitmes külas elab veel rannarahvas?" Ja loetleti üles kõik need külad: "Lūžõs, Pizās, Īrakilās, Ūdkilās ja Sīkrõgõl, Irail Pitrõgõl, Kuošrõgõl, ja Sānagõl, Vaidõl, Kūolkas, Mustanummõl, sāl jelā-

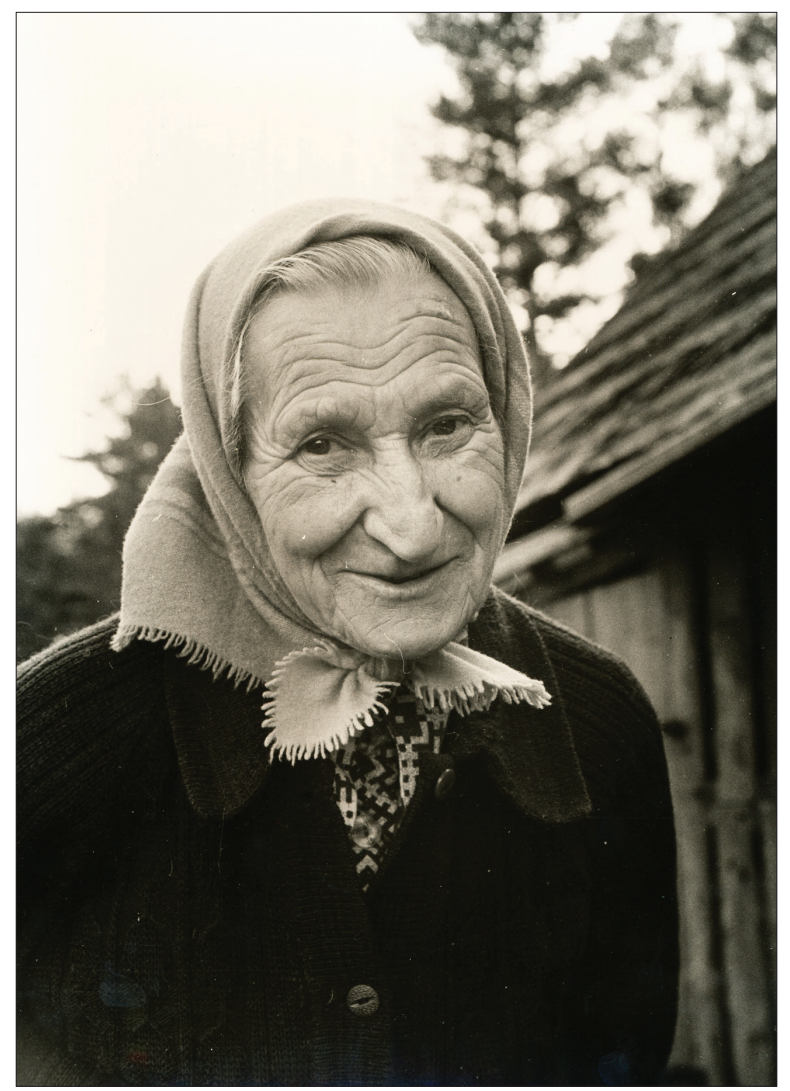
böd rändalizt" [seal elavad randlased - s.t liivlased] (NMV-19).

Küladel on liivikeelsed nimed. Kuid mitte ainult küladel. Alvīne Mūrniece Lūžņast selgitab:

Igal metsal, igal kivikangrul, igal teerajal - igaühel on oma nimi. Mäg on kalns [mägi] ja dertara on läti keeles dārvalks [juga], no muidugi - Dārvalka kalns läti keeles ja liivi keeles on siis Dertaramäg [Joamägi]. Ja niitudel on nimed. [---] Jaa, need inimesed, kes siin 
elavad, need ju saavad kõik aru, ütle, kuidas tahad, liivi või läti keeles. Neile on ainult neid nimesid vaja. (NMV-2.)

Aina Bolšing jutustab muistendi, kuidas on tekkinud Dieviṇi järv [Jumalajärv]. Sidudes selle loo oma sünniaastaga, põimib ta muistendi oma eluloojutustusse. Ühtlasi on see näide, kuidas elukeskkond lahustub eluloos ja vastupidi - inimeste elud, nende elukeskkond ja jutumaastikud moodustavad sidusa terviku:

Parunile kuulusid karjamaad, kõik järveniidud. See oli ka kunagine Dievin, järv, mis nü̈̈dseks on kuivendatud. Sellest on terve lugu, kuidas parun ratsutanud hobusega, ja see järv jälle nagu nastik siuelnud hobuse jalgade küljes ja tõmmanud ennast kaasa. Parun ratsutanud siis hobusega tiiru ümber selle niidu ja nii tekkinudki järv. Hiljem võtnud parun sellele järve endale ja käsitsi oli kaevatud kraav, mis järve ära kuivendas. Aastal 1837 oli kuivendatud - see oli üks aasta ja aastasada enne minu sündi. Parunil oli karjamaad vaja, tal oli palju loomi. (NMV-2634.)

Sisemaast eraldasid liivi külasid metsad, sood, mudased nõod - vigād. Emīlija Rulle mälestustes tulevad esile parimad jõhvikakohad, mis omakorda liituvad vanade lugudega looduslikust tõkkest, mis kaitsesid rahvast röövlite eest:

Väga mudane oli Pempe soo... ehk oli seal järv olnud, ja sealt läks ka selline oja läbi. Sellest soost on üle tehtud sõidetav tee Dundagasse... Päris soo keskel on selline mägi - Tuba mägi. Maa poolt sai ainult ühe koha pealt sinna Tuba mäe peale saada. Räägitakse, et sellel Tuba mäel oli kunagi olnud küla ja talud. Kui need röövlid tulnud, siis naised ja lapsed on põgenenud sinna Tuba mäele. Ratsanikud ei pääsenud sinna ligi, nii hirmus mudane, vanad puud peal, meie kah ei saand ligi. Sinna võis marjule minna-jõhvikale. Ilus, ilus. Selline suur karjamaa ja seal sees see mägi. Ma kunagi otsisin, kas pole mõnda talukohta veel. Ümberringi kõik mudane, suur, suur soo. Pempe niitudel on vanad liivlased kunagi heina niitnud. (NMV-19.)

Luiteliival kasvas hein kiduraks, seda sai niita heal juhul alles pärast jaanipäeva. Sellepärast kasutati karja- ja heinamaadeks metsa- ja sooniite. Heinaaeg kajastub paljude jutustajate mälestustes. Talunikel olid metsaniidud, kuhu mindi heina tegema mitmeks päevaks. Heinateo ajal ööbiti küünides, tehti öiseid lõkkeid, jutustati tondilugusid ja isegi nähti tonte, mida Paulīne Kḷaviṇa mäletab järgmiselt:

Meie niitsime heina ühel kindlal ajal, paar nädalat pärast jaanipäeva, vana kalendri jaanipäeva paiku. Maa oli jagatud asundustaludeks. Asundustele määrati heinamaad sinna, kus pidi minema läbi Baži metsast, 
ja pidi minema läbi Vecvagari niidust. [---] Õhtul hõikasime üksteist ja selle järgi tundsime üksteist ära. Hõikasime: uu-uu, ja õhtul tulime kokku. Aga muide oli üks selline juhtum. Magame kü̈̈nis. Ja naabril kü̈̈ni pole. Ta tuleb meie kü̈̈ni magama. Aga eelmisel õhtul on juba jutte räägitud, kuidas need karvased kõnnivad ringi ja kuidas nad on kõndinud, ja kuidas nad hingesid võtavad, kuidas nad on lennanud üle niidu ja tulevad külla ja võtavad heina ära ja viivad üles õhku ja ära.

Magame seal kü̈̈nis. Mina oma venna Andrejsiga magan nii küüni keskpaigas, aga see Oskars naaberheinamaalt tuleb ja heidab sinnasamma nurka, luugi ligidale. Ja öösel me kuuleme, et väljas kiristatakse hirmsasti hambaid ja öeldakse nii: "Ma nägin, et päeval olid siin inimesed ja mul on nende hinge vaja." Ja nii hirmsasti kiristab neid hambaid: "Kuidas ma saaksin sinna kü̈̈ni peale üles?" Ja ta võtab nii... Meil on väljas heinaveopoomid, ja ta võtab selle poomi, ja lükkab just sinnapoole, kus see Oskars magab. Ja minu vend ütleb nii: "Oskars, tule siia! Ta ju torkab just sinu poole, jah.” Ja see Oskars roomab ka meie juurde. Aga see väljaspool nii õudselt kiristab neid hambaid... Ta räägib: "Ilma eluhingeta ma ära ei lähe.” Ja nüüd jääb nii vaikseks. Meie ka oleme vait. Ei, ta jälle kiristab hambaid ja jälle. Siis lausub nii: "Ei, ma pean minema. Võib olla, et ta tukub seal kuhja kohal.” Nü̈̈d me vaatame, võib juba näha seinapalkide vahelt, et ta läheb minema. Ja suur kott seljas, jah. Ja ta läheb, ja läheb just sinna, kus Oskarsil on see heinamaa. Noh, ja kui tuli hommik, siis tuleb teine vend Jānis kodunt. Ta oli koju läinud vaatama, et võibolla on laev tulnud. Ja kui laev on tulnud, siis peab laeva laadima. Siis saab seal raha teenida. Ja kuna laev pole tulnud, tuli ta öosi tagasi. Ja siis lõpuks me... Andrejs sai juba aru. Jānis tulnud tagasi ja tahab seda Oskarsit hirmutada. (NMV-86.)

Eredad lapsepõlvemälestused heinaajast sünnikohas elustuvad ka muusikul Jānis Ērenštreitsil ja arstil Valdis Dambergsil, mõlemad arutavad vaheldumisi:

Ma pole kuskil mujal nii nautinud heinaaega kui Sīkrõgis. Midagi ei ole kaunimat kui haritud heinamaa. Ja sīkrõglased oskasid selle heinaaja korraldada nii, et inimesi ei väsitanud, see oli peaaegu nagu pidu. Neil olid seal väga head tavad - heinamaal tulid kõik üksteisele appi, kõik mehed, kes olid jõudsas eas, need läksid loogu võtma üksteise järel ja mina muide ka nende järel. Nad tegid seda väga hoolikalt ja kunagi ei olnud nii, et väsitaksid, et meeleheiteni, et seal jõuetuna langeksid maha. Vahepeal nad tegid pausi, nad vaatavad, et 13-aastane poiss, nad võtavad aeglasemalt, vaatavad, siis üks tuleb mulle appi, aitab vikatit paremini luisata. (NMV-300.) 
Näeme, et liivlaste lugudes on kohad väga konkreetsed: neil on nimed ja neil on ajalugu, mis on läbi põimunud nii vanadest lugudest kui ka mitme põlvkonna tegudest, näiteks röövlite eest varju leidmisest marjanoppimiseni. Need ajakihid ei ilmu lugudesse siiski kronoloogiliselt korrastatuna, sest jutustus ei ole nagu sirge joon, mis ühendab minevikku ja olevikku. See meenutab rohkem jõekääre. Just nii, nagu jõekaldad, on ka jutul oma siseloogika, juhtivad vood ja harujõed, kuhu sekkuvad kõrvalmotiivid, ümbrus, varjundid, üksikasjad. Järgnev näide on Valdis Dambergsilt:

Meie talu oli Sitamäe juures. Mulle oli maast-madalast räägitud, et paljud on seal kaevanud. Minu vanaema, isaema, oli rääkinud, et seal olid elanud röövlid, et seal olnud nende elupaik ja kõik need varandused, ja siis merele läinud kõiksugu köied. ${ }^{3}$ Mina ise kah käisin seal kaevamas, sest seal üleval oli nii, et kui trampida, oli nagu kõmin. Loomulikult midagi sealt välja kaevata ei saanud.

[---]

Ja minu vanaisa vend oli maganud heinas ja ühel ööl oli ta näinud und, et üks mehike tulnud, kui kell lõi kaksteist: "Ära võta kedagi kaasa, võta labidas, mine kaevama ja sa saad selle." Ja ta nagu rumal maganud edasi, läinud kaevama pärast, siis pole aga midagi saanud. Aga seal olevat ahjupotid välja kaevatud, nii mõnigi sīkrõglane teinud endale ahju nendest pottidest, mis leidnud, aga raha leidnud pole keegi. (NMV-300.)

Nii tulevad esile erinevate põlvede tegevuskihid, kuid ka tegevuse aluseks olnud motiivid, mille seob tervikuks kodupaiga looduskeskkond.

Liivlaste jutte kuulates ei saa ei uurija ega intervjueerija mööda tõdemusest, et paljudel liivlastel on kunstnikuvõimeid. Kalalkäimisega sobis ehk luuleline maailmatunnetus hästi? Seda võib näha liivi luulevalimikust Ma Akūb Sīnda Vizzõ, Tūrska! [Olen sust, tursast, kavalam], mille autoritest suur osa teenis leiba merel. Kuid sellest annavad tunnistust ka paljud maagilised motiivid oma lähiümbruse kirjeldamisel. Raske on eristada tõsielu-mälestusi muistenditest Lizete Švānenberga juttudes. Tema eluloos pole selgeid piire tegelike sündmuste ja kujutluste vahel. Oma mõju on siin olnud ka eesti uurijal Oskar Looritsal, kes on järeleandmatult kuulanud ja kirja pannud tema ema Marija Leite liivi keelt ja pajatusi.

Kui ema tuli saunast, siis ta ütles: "Nü̈̈d on kõik puhtad, nü̈̈d, Maarjaneid, ma panen sulle vee ja viha - nü̈̈d pese sina!” Ja mina jälle ütlesin emale: "Kas siis ta peseb ka, see Maarja-neid?” Ema ütles: "Peseb küll.” Aga ma panin mitu korda tähele - ema kogu aeg kallab nii täis, aga kui ma läksin vaatama pühapäeva hommikul, siis oli vähem. Noh, ja kui ta hakkas rääkima Keizari Marijaga liivi keeles, ma ju liivi keelest saan 
kõigest aru. Siis see Ķeizari Marija ütles: "Nü̈̈d on Maarja-neid end pesnud, tema'p selle vee on ära sulistanud.”

Meie läheme Karumetsa, kus meil heinamaad olid. Ja täiesti valge madu, nastik, ronis mööda männipuud üles. Ja need teised lõid teda. Ma olin niisugune tüdruk. Ma ütlesin: "Mis teie siin teete?" Valge nastik. Ma ütlesin: "Aga miks te teda maha lööte?” Ja siis tuleb üks selline vana. Ta ütleb: "See on ussikuningas, seda pole vaja maha lü̈̈a!” [---] Ei löönudki, see nastik pääses. Nii ma päästsin igasuguseid. Mina nastikut ei löö kunagi. (NMV-3.)

Kuulates Ženija Belte mälestusi, saame väljendusrikka jutustuse liivi vanaemast, kelle eluaeg langes 20. sajandi alguse rasketesse aastatesse. Ajaloolistest ja argielulistest seikadest (nagu rongi pealt tulijatelt uudiste kuulamine, maarohtudest teekeetmine, salvidega arstimine, sõjaaegsete oludega silmitsi seismine) ilmneb, et “tõeliseks liivlaseks” olemine seisneb liivi keele kõnelemises ja kodukoha hoidmises:

Emapoolse vanaema nimi oli Nēze Brencis, sündinud Botter. Ta oli tõeline liivlane, sündinud Miķeltornises. Vanaema, nagu ma lapsepõlvest saadik mäletan, pidas väga lugu oma liivi päritolust ja alati, kui vaid kohtas mõnd liivlast, kes oskas liivi keeles rääkida, siis ta rääkis ainult liivi keeles. Ja ma veel mäletan oma lapsepõlvest, kui ma kitsarööpmelise rongiga sõitsin, siis eriti vanad iralased, need üldse läti keelt ei rääkinudki, ainult liivi.

Ta tahtis kõiki uudiseid teada. Ja siis seal oli nii, et see rong meil, kitsarööpmeline, tuli pärastlõunal. Nendes rannakülades sel ajal see oli ainus küla kokku tulemise koht, kui väike rong tuli. Ja siis vanaema korraldas juba aegsasti kõik oma tegemised, et saaks jaama minna. Ja ka läti keeles ta rääkis sellise... natuke sellise... omapärase liivi aktsendiga.

Ja siis ta tegi maarohtudest teed. Pizes (Mik,l,tornises) oli üks tüdruk, minuvanune tüdruk... me koos käisime leeris. [---] Tal tuli naha peale hirmus haigus. Ta oli nï õnnetu... noh, küllalt suur tüdruk juba, teismeline. Nad olid kõiksugu arstide juurde teda viinud - aga ei saanud abi. Aga minu vanaema tegi ta terveks. Ta tegi selliseid salvisid. Ja see tüdruk käis tema juures - ja kadus see hirmus lööve, need sügelised, või ei tea mis, aga... noh nii, tema oskas küll aidata igasugu hädade puhul.

Vanaemal oli palju lapsi, kellest osa suri kui sõjapõgenikud ja nad on maetud Venemaale. Ise oli ta sõja ajal murdnud jalaluu, kuid läbi raskuste, nälja, sekelduste ja kannatuste jõudnud õnnelikult koju. Nii Esimeses kui Teises ilmasõjas läksid kõik meie ranna elanikud, kõigi 


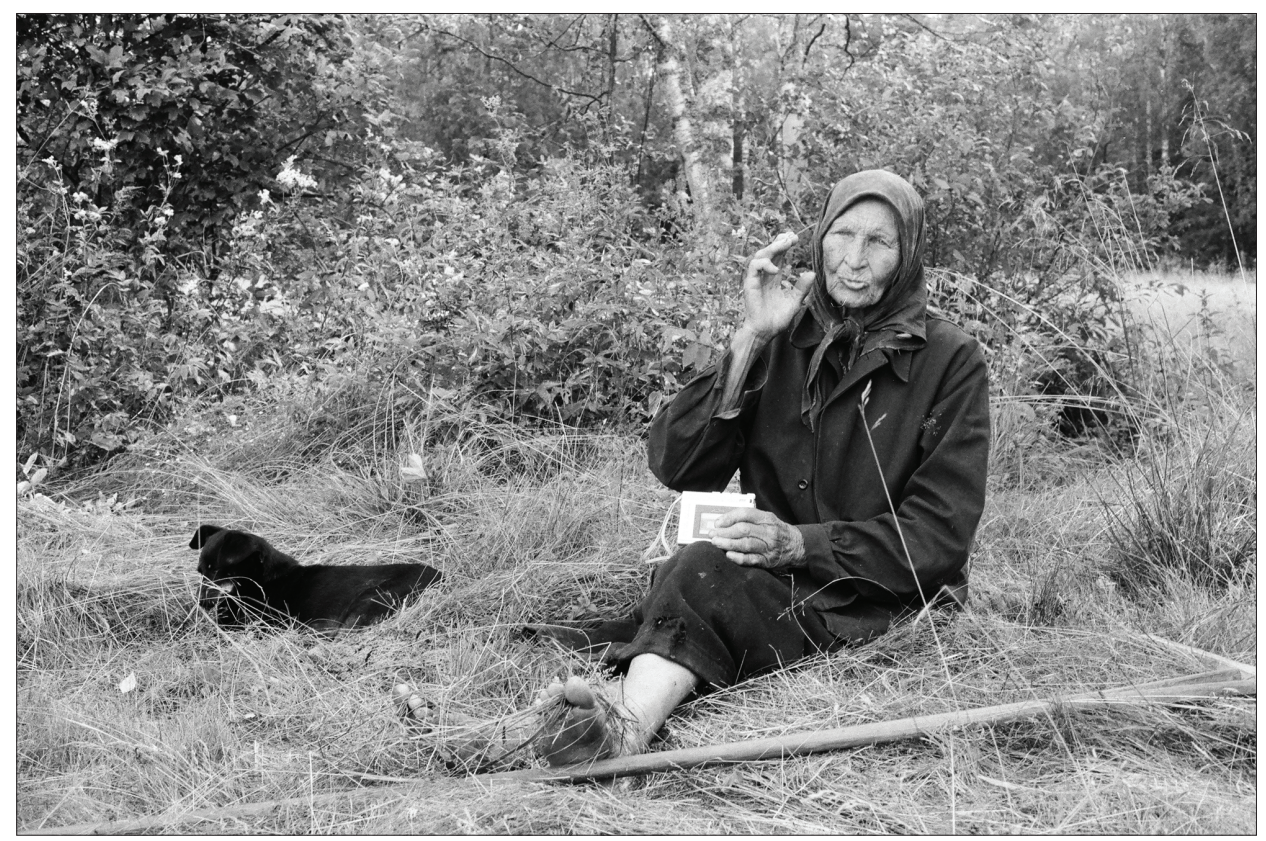

Lizete Švānenberga. Vaira Strautniece foto 1987.

peredega. Aga mis on iseloomulik - kõik tulid tagasi oma kodukülla. See kodupaik tõmbas väga enda poole. Kuigi pärast sõda oli rannas elu väga kehv, aga see kodupaik tõmbas koju tagasi. Selline oli see rannaelu tookord. (NMV-1635.)

Pärimuslikus ajaloos leidub teave, mida inimene oma elust, peresidemeist ja elukeskkonnast tingitud muudatustest jutustades annab. Jutustaja isikupära, enda teadvustamine aja, sündmuste, tavapärase elulaadi ja elukoha suhtes iseloomustab väärtusi, mis kõige tõenäolisemalt antakse põlvest põlve edasi tunnistusena kõlblusest ja elukeskkonnast, mis kuulub liivi kultuurilukku. Eelnevast tuli nii lugude kui ka tegevuste kaudu esile inimese ja koha seotus. Lugude kuulaja kõrvu jääb kõlama ka lugude jutustuslikkus: pikad teemaarendused ja poeetiline keelekasutus, mis viitab varasemate jutustamiste hõlmamist siin käsitletud intervjuudes. Ka see autobiograafilise jutustamise viis on liivi kultuuritraditsiooni osa. Peab lisama, et viiekümne nõukogude aasta jooksul, mil liivi külades laiutasid sõjaväebaasid ja kehtis piiritsooni režiim, on kohalike elanike arv tunduvalt kahanenud. Suurem osa vanade liivi suguvõsade järeltulijatest ei ela enam oma ajaloolisel asualal, tulevad sinna ehk vaid suvitama. 


\section{Kuulates mustlaste jutte}

Järgnevalt tutvustame mustlaste elulugusid. Eesmärgiks on jälgida nii seda, mis on jutustajatele iseloomulik ja eriline kui ka seda, mis ühendab neid kogukonnaks. Vaatluses lähtume taas jutustajate endi jutustamismustritest.

Rahvusliku suulise ajaloo arhiivis leiduvad intervjuud mustlaste esindajatega (arvult 21) paistavad esmapilgul üksteisest väga erinevad, mis osutab sellele, et mustlaste kogukond Lätis on seesmiselt ebaühtlane. Siiski on tunnuslik, et iga jutustaja näitab oma loos enda otsest või kaudset sidet oma rahva saatusega 20. sajandil. Juttudest tuleb esile, et kuni Teise maailmasõjani elasid mustlased igati tavapäraselt: nad tegelesid peamiselt talu- või käsitööga, muidugi ka hobuseparistamisega. Moraalse ja füüsilise hoobi sai rahvas siis, kui algas Teine maailmasõda ja koos Saksa vägede sissetungiga anti välja korraldus, mille täitmine võis Lätimaa mõnedes piirkondades tähendada mustlasrahva hävingut. ${ }^{4}$

Järgnevalt tutvustame lähemalt episoode, milles väljenduvad mustlastele iseloomulikud eluloo-jutustuse teemad. Lisame siinkohal, et need eluloointervjuud on salvestatud põhimõttel, kus intervjueerija ergutab jutustama ja hoiab loo kujundamisel alal eluloolist perspektiivi, kuid laseb jutustajal vabalt valida teemad ja nende järjestuse.

Intervjuu Jānis Neilandsiga on salvestatud mitmel kohtumisel, mis toimusid 1994. aastal. Tema loost kooruvad välja elukäigufaktid. Neilands sündis 1918. aastal Venemaal Lätist Esimese maailmasõja ajal sinna pagenud peres. Teise maailmasõja alguses sattus ta vangi Saksa poolel, hiljem tegi kiire karjääri Punaarmees. Jānis Neilands on hea jutustaja, mistõttu kuulaja saab toimunust teada varjundi- ja detailirikka jutustuse kaudu, leides, et loo minategelase saatust on suuresti mõjutanud suuremad või väiksemad juhused, aga ka isikuomadused, nagu näiteks ausameelsus. Nii näib kuulajale esialgu absurdne, et noor mees, saades teada, et teda otsitakse taga, annab end Saksa politseile ise üles ja satub selletõttu mitmeks aastaks vangi- ja töölaagritesse. Kuid loo edenedes selgub, et just see otsus tegi võimalikuks tema kõrvalejäämise mustlaste holokaustist aastail 1941-1942. ${ }^{5}$ Sündmuste ja õnnelike juhuste poolest on rikas ka episood, kus ta kirjeldab, kuidas ta aitas vennal vangistusest põgeneda ja kuidas nad redus olles kahe rindejoone vahele sattusid ning seejärel Punaarmee juurde jõudsid.

Tema vanematel oli enne sõda olnud üsna suur talu Kandava linna lähedal. Neilands näitab end oma loos poisina, kes on maast-madalast palju tööd teinud, palju lugenud, hästi õppinud ja olnud oma klassis üks parimaid. Koolipõlves olid küll teised lapsed teda kiusanud ja hüüdnud: "Mustlane, mustlane!", kuid tollal Kandavas kakelnud omavahel kõik - linlased maalt tulijatega, mustlased lät- 
lastega jne. Tõsi, see kiusamine kujundas pinnase sotsiaaldemokraatlike ideede pooldamisele, millest omakorda tulenes astumine komsomoli. Võimalik, et üks põhjusi, miks Jānise jutus on teiste lugudega võrreldes nii vähe mustlaslikku, on asjaolu, et enne Teist maailmasõda elas mustlaste kogukond hajutatult (vrd Malkki 1992). Teiseks võisid seda mõjutada Jānise isikuomadused, mis võimaldasid tal saada instruktoriks ja hiljem ka seersandiks sõjaväes.

Erinevalt eelkirjeldatust struktureerib oma loo Kārlis Rudevičs. Seda erinevust tingib vähemalt kaks asjaolu: ta on eelkirjeldatud jutustajast põlvkonna jagu noorem ja ta on Läti mustlaskultuuri üks tuntuimaid esindajaid. Ta alustab oma loo jutustamist suguvõsa ajaloost, asetades selle mustlaste kogukonna ajaloo, sotsiaalse struktuuri ja kultuuri üldpilti. Ta sündis 1939. aastal Vangažis kümnelapselisse perre, mis põgenes sõjaaegse mustlaste hävitamislaine haardest Riiga. Seal õnnestus neil "osta” teine nimi, millest tulenevalt loeti neid lätlasteks. Pereliikmetest käisid tööl ainult valgetverd mustlased, et nad ei langeks repressioonide ohvriks - strateegia, mis oli peret juba kord päästnud.

Ma mäletan, et siis, kui tulid sisse venelased, meie olime keldris peidus. Siis tulid veel viimast korda [omakaitse tegelased] sisse. Keegi oli koputanud, et seal elavad mustlased ja saatis need omakaitse mehed peale. Selles segaduses, kui tulid venelased, nad oleksid meid ka maha lasknud. Tulid keldrisse automaatidega ja: "Zigeunisch?” Ja ema oli valget verd, siniste silmadega, mustaverelised peideti ära: "Alle Lettisch! Alle Lettisch!" Ja siis nad läksid ära. Minu õde, minust noorem, see oli täiesti blond, suurte silmadega - see pandi ette, ja ema oli ka valget verd. (NMV-2108.)

Ellujäämist toetasid eelmainitud strateegiale lisaks veel mustlastele iseloomulikud tunnused, millest ta mainib kunstnikuloomust, taiplikkust ja leidlikkust keerukatest olukordadest väljatulemiseks. Ta räägib, et vanemad vennad olid alati pääsenud ühte või teise sõjaväkke värbamisest, sest nad pole olnud, nagu Kārlis Rudevičs sõnastab, lihtsameelsed, kes näevad ainult üht elu poolt, vaid nad on kavalad ja osavad.

Kui jutustaja oli seitsmeaastane, suri tema ema, varsti pärast seda ka isa. Kuna vanemad vennad ja õed olid juba suured, jäi Kārlis Riia korteris üksi peremeheks. Ilmneb, et nende peres oli alati väärtustatud tööd ja töökust, mistõttu tal polnud raske endale elatist teenida, samal ajal jätkata õpinguid keskkoolis ja tegeleda harrastustega - luuletamise, maalimise ja musitseerimisega. Kultuurihuvi viis tema hiljem ühe ta peamise eluülesande juurde - arendada ja populariseerida mustlaste kultuuri. Järgmisele (täisealiseks saanu) eluetapile on eluloos tunduvalt vähem tähelepanu pööratud kui lapseja noorpõlveperioodile. Selles elulooosas keskendub ta hoopis mustlaste seltsi tegevusele, mustlaste sotsiaalsetele probleemidele tänapäeval. Intervjuu lõpus 
väljendab ta pahameelt stereotüüpsete ettekujutuste üle, mida massiteabevahendid mustlastest levitavad. Vaatamata üsna katkendlikule jutustusele, on Kārlis Rudevičs oma eluloos hõlmanud kõik tähtsamad eluetapid - lapsepõlve, kooli- ja tudengipõlve, iseseisva elu alguse, töökogemuse ja elu vanaduspäevil.

Kuigi Kārlis Rudevičs on oma jutustusse põiminud ulatuslikke kõrvalepõikeid mustlaste ajaloost ja traditsioonidest, siis tõelisesse mustlasmaailma viivad kuulaja ikkagi kolm mustlasnaist - Lūcija Stepane, Olga Burkevica ja Valija Pauča. Just nemad, asetades oma loo keskmesse argielu, avavad mustlastele omase elustiili. Samas proovivad nad leida sõnu, et rääkida sündmustest, mis on oma koha leidnud mustlaste kollektiivses mälus, kuid on avalikkuses veel läbi rääkimata. See puudutab episoode, milles nad räägivad 1942. aastal toimunud mustlaste holokaustist või genotsiidist, mille käigus hävitati peaaegu kaks tuhat mustlast - ligikaudu pool Läti mustlaste arvust sel perioodil. Kuigi intervjuu-esitused on katkendlikud, paljugi jääb ebaselgeks ja arusaamatuks, võimalik, et ka jutustajatele endile, on mustlaste tragöödia teema neis juttudes kesksel kohal. Raskusi sellest kõnelemisel põhjustab ehk seegi, et mitte ainult Läti, vaid ka maailma ajalookirjanduses on sellest räägitud väga vähe.

1928. aastal sündinud Olga Burkevica on üks väheseid mustlasi, kellel õnnestus pääseda Rēzekne linnast, kus 1942. aasta 4. ja 5. jaanuaril lasti maha enamik linnas ja maakonnas elavatest mustlastest (Vestermanis 1993). Põgenedes sattus jutustaja koos oma perega Ventspilsi, kuid varsti pidid nad sealtki lahkuma, sest Saksa okupatsiooni ajal ei tohtinud mustlased elada linnas. Peale selle ei tohtinud nad rääkida oma keeles ega viibida tänaval pärast kella kümmet õhtul.

Intervjueerija: Kas te pidite sõja ajal ka kuhugi põgenema?

Olga Burkevica: See oli saksa aeg. Linnas ei tohtinud üldse mustlased elada. Siis mindi maale ja tehti talutöid.

I: Või lihtsalt tuli keegi ja ütles, et te peate ära minema?

O. B.: Mitte lihtsalt inimene, vaid politsei. Anti kuupäev, millal peab linnast kaduma, ja kõik.

I: Ja kui ei kao?

O. B.: Kui ei kao, siis teadagi-kõmm ja läbi.

I: Kas te tundsite kedagi, kes maha lasti?

O. B.: Kes neid enam mäletab. Paljusid tunned, aga meie enam ei mäleta. Mu tädi lasti maha Kuldīga taga. Tulid, võtsid kinni. [---] Igal pool lasti, mõned kohad olid ainult, kus ei lastud.

I: Kui kaugele Ventspilsist te pidite põgenema?

O. B.: Linnast ära. Siin, Ventspilsis ei tohtinud kogu ümbruses ka elada.

Rajoonis kah. Siin ei tohtinud olla.

I: Kuhu te siis läksite? 
O. B.: Me olime Kuldīgas, Sabiles. Kusagil ei olnud sellist püsivat elu.

I: Kui kaua teil tuli sellist redutamist?

O. B.: Kui vahetus valitsus, kogu Saksa aja. Saksa ajal ei tohtinud isegi mustlaskeeles rääkida. Kui oli kell üle kümne õhtul, ei tohtinud käia, siis võeti kinni. (NMV-1661.)

Olga Burkevica intervjuust ei moodustu jutustust. Pigem annab ta lühidaid, katkendlikke vastuseid intervjueerija küsimustele. Seejuures ei ava ta isiklikke tundeid, emotsioone, suhtumist. Valija Pauča, kes oli toimunut näinud lapsepõlves, räägib küll rohkem, ent ka temalt tuleb see küsimustega välja meelitada. See haakub mõneti vaevarikka, tollal lapsele mõistetamatu tegelikkusega. Esimest kokkupuudet mustlaste genotsiidiga kogeb Valija Pauča küllalt ebatavalistes oludes, kui tantsupeol Riia Mežaparksis lastakse maha tema isa. Intervjuus järgneb raskesti hoomatav episood, millest võib aru saada, et alguses õnnestus perel põgeneda Kuldīgast, kus lasti maha väga palju mustlasi, siis hiljem võeti ema koos lastega kinni ja viidi Stende jaama. Stende jaamas eraldati naised lastest ja saadeti koos meestega "kuhugi välja" - kuhu, seda jutustaja ei teadnud. Vagunitesse jäetud mustlaslapsi oli piinatud, sealhulgas ka tol ajal kuueaastast Valijat. Ta kõneleb sellest nii:

Valija Pauča: Mul oli nii hädavaevu - maha ei lastud, aga võeti, seoti puu külge kinni-seoti kinni ja siis selliste malkadega peksti. Ma ei suutnud välja kannatada, ma kukkusin maha, minestasin. Nemad võtavad ja kallavad vett peale. Võtavad kaevust külma vett ja kallavad peale - et toibuksid. Ja nii edasi, kuni lõpp käes. Aga mina jäin ellu.

Intervjueerija: Kas seal oli veel kedagi, või te olite üksi?

V. P.: Noh, seal sellised suuremad lapsed, kes seal olid... seal oli palju selliseid lapsi.

I: Ja kas seal keegi surma ka sai?

V. P.: Oli palju. Ja suuri inimesi oli ka maha lastud. (NMV-1662.)

Tema mällu on jäänud omaaegseid jutte sellest, kuidas mustlastel kästud enne mahalaskmist endile haud kaevata; kuidas naistel on enne mahalaskmist juuksed maha lõigatud; kuidas laste pealt säästetud kuule: "Lapsed võeti jalgupidi ja taoti vastu mände. Siis ei pea kuule raiskama." Tänu kohalike elanike julgusele õnnestus osadel mustlastest põgeneda, varjuda metsa. Valija Pauča selgitab, et Stende ümbruses olnud tookord peidus väga palju mustlasi - nii Ventspilsist ja Talsist, kui Kuldīgast ja Saldusest. "Ehitanud sellised onnid ja siis elasid. Okaspuude okstest tegid sellised karuonnid." Elanud "näljas, poolsurnult", kuid kõik üheskoos. Mõne aja pärast läks lähedal asuv laohoone põlema ja tulekahjust alanud suur segadus, mille tagajärjel osutus võimalikuks tagasi minna Kuldīgasse: "Minu ema võttis kah ühe hobuse ja vanker oli seal, ja siis 
ladus meid kõik sinna sisse. Sai rakmed. Ja siis me põgenesime jälle edasi. Siis me põgenesime tagasi Kuldīgasse." Kuldīgas seadis pere end sisse, hoolimata sellest, et endine kodu oli tühjaks varastatud. Valija Pauča alustas kooliteed ja lõpetas Kuldīga algkooli kuus klassi eriliste raskusteta. Ema omakorda oli leidnud tööd kojanaisena. Valija Pauča läks pärast kooli tööle mööblitsehhi Kuldīgas, hiljem, kui nad olid läinud elama Ventspilsi, kalatehasesse.

Valija Pauča on üks neist paljudest mustlastest, kes kasutas nõukogude ajal tekkinud võimalust töötada ametlikult kas tehases, kalatööstuses või kolhoosis. Nõnda katkes sajandeid kestnud rändajate eluviis. Riigitehaste ja kolhooside kaotamine 1990. aastatel põhjustas taas ränki muutusi - suur osa mustlastest jäi töötuks. See asjaolu toob elulugudesse kaasa ühe mustlasi ühendava aspekti, nimelt positiivse hinnangu nõukogude ajale. See esiletulek suunab uurija enam küsima, kuidas mustlaste elulugudes üldiselt mõtestatakse lähiajalugu - nõukogude aega. Ilmneb, et see on üks läbivamaid, kuid samas ka vastuolulisemaid teemasid mustlaste elulugudes. Ühelt poolt pakub nõukogude aja kogemus mustlastele võimaluse rääkida positiivsest minevikust, mis seostub väärtustele orienteeritud enesemääratlusega. Siis oli igaühel võimalus käia koolis, igaüks võis leida tööd ja kuigi vaeselt, elati ikkagi ära. Nõukogude aega hinnatakse mustlaste lugudes kui perioodi, mil iga inimene, sealhulgas mustlane, võis valida äraelamise mooduse: kas teha tööd pidevalt või hooajaliselt või hoopis tegeleda mitteametliku tööga ehk "spekulatsiooniga”. Ühtlasi väidavad nad, et mustlased ei tundnud end siis eemaletõugatuna. Siiski osutab nõukogude aja positiivne kogemus samas ka sisemise konflikti olemasolule. Konflikt ilmneb ühelt poolt mustlaste enesemääratluse ja teiselt poolt kultuuriliselt kujunenud eluviisi (ehk argielu ja argiteadvuse) vahel, ja samas ka küsimuses, milline peaks olema mustlaste elukeskkond, et nad integreeruksid ühiskonda (pidev elukoht, haridus ja töö). Ühelt poolt meenutavad mustlased nostalgiliselt marja- ja seeneaegu, lõkkeid ja vanade meeste jutte, väljasõite hobustega. Teisalt ei taha nad aga erineda teistest Läti elanikest.

Küsimus mustlaste enesemääratlemisest on korduvalt esile tõusnud just 2013. aasta suvel tehtud intervjuudes, seda intervjueerijate küsimustele nii otseselt kui kaudselt vastates. Viimane ilmneb, kui süveneda mustlasrahva eneseteadvusega seotud aspektidesse, mida intervjueeritavad on väljendanud, või kui analüüsitakse narratiivi struktuuri, sõnade ja lausekonstruktsioonide valikut. Üks küsimusi, mida tahtsid selgitada nii uurijad kui ka jutustajad ise, on küsimus: kes on nn tõeline mustlane. Siinkohal tuleb täpsustada, et "tõeline”, vahel ka "päris" oli mustlaste endi valitud täiend. Ausma Leimane Kuldīgast lausus juba intervjuu alguses lühidalt, et "Päris mustlased, nagu kunagi olid - nüüd selliseid enam pole." Tema jutustusest ilmneb, et "päris mustlasi” võis kohata 20. sajandi alguses ja veel sõdadevahelisel perioodil (1920.-30. aastatel), 


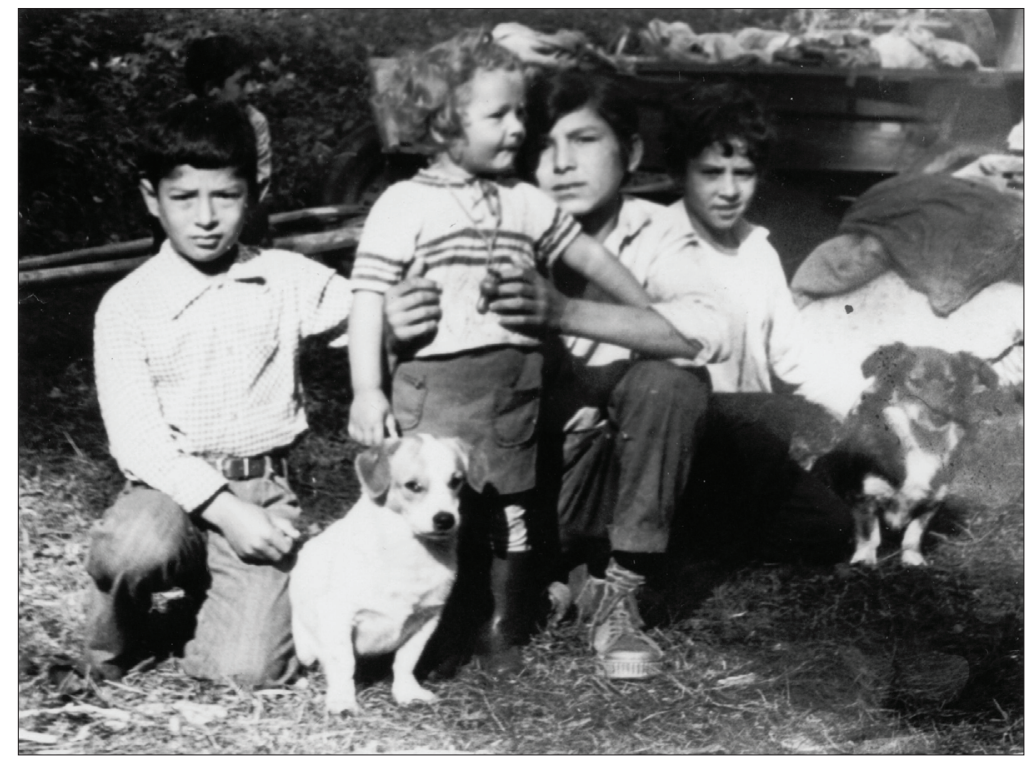

Lapsed mustlaslaagrist Ventspilsi lähedal 1970. aastate lõpus. Māra Zirnīte foto.

kui mustlased pidasid hobuseid, mustlasnaised kandsid kohevaid seelikuid ja pluuse ja tegelesid peamiselt ennustamisega (NMV-4070).

Täiendit "tõeline" tarvitatakse mitte ainult mustlaste riietuse või tegevusala kohta, seda kasutatakse ka mustlaste elulaadi iseloomustades. Eriti on jutustajate mällu sööbinud aeg, kui mustlased läinud suviti liikvele. Zelma Ignāte, mustlasnaine Talsi linnast, kirjeldas:

Aga mina olen veel trehvanud seda mustlaste elu. Isal oli valge mära. Meie sõitsime, terve rodu mustlasi. Kohtusime teistega, õhtul kõik lõkete juures, mehed koos ja naised koos. Oli väga ilus. (NMV-4078.)

Ka näiteks Ziedonis Leimanis väidab:

Kunagi olid mustlased ühtsed, elasid koos, sõitsid koos ringi, koos käisid metsas - nü̈̈d on igaüks omaette. (NMV-4071.)

Sõidud ja ühise lõkke juures veedetud suveööd olid olulised suhete loomisel, seda mitte ainult kogukonna vaid ka pere piires. Mustlaste kogukonna seesmine hajumine, omaette olemine on mustlaste sõnutsi üle võetud lätlastelt. See suunab uurijaid küsima kultuurilise identiteedi konflikti kohta, mille on põhjustanud muutused ühiskonnas. Mustlased ei ole identiteedimuutuste osas üksmeelsed. Isegi ühe ja sama pere piires võib valitseda erinev arusaam sellest, milline peab 


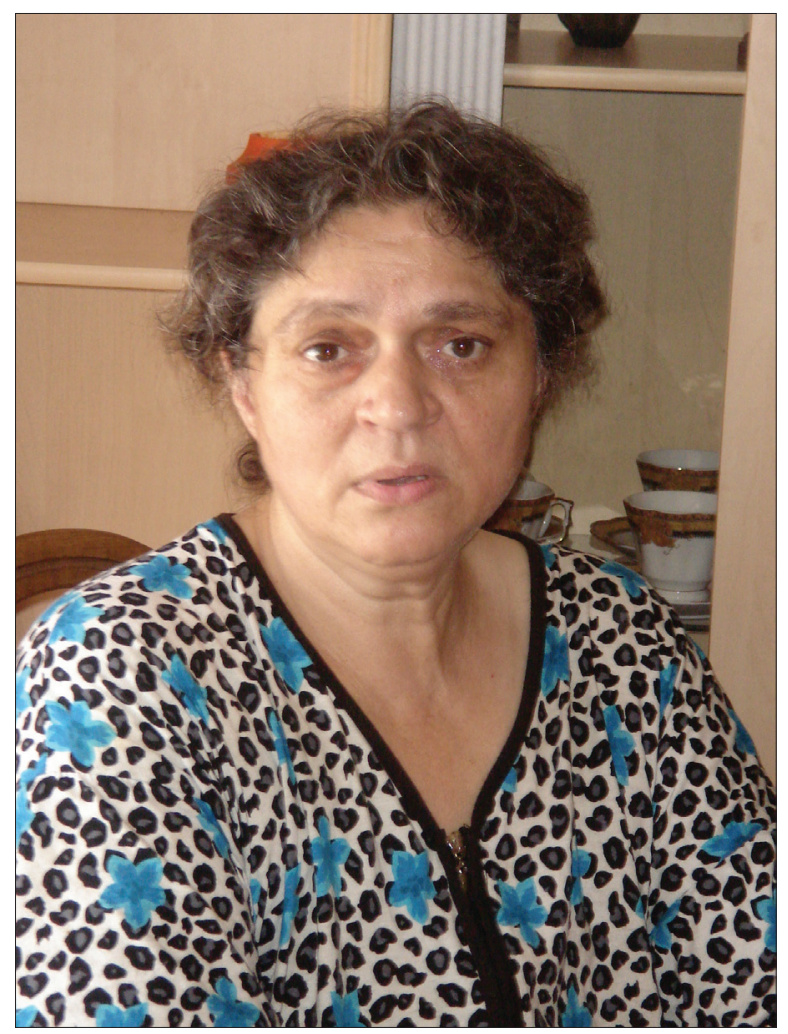

kaasa Ziedonis arvab, et mustlased peavad ajaga sammu pidama, mistõttu neil tuleb loobuda mõnedest tavadest, näiteks hobuste paristamisest või rändavast eluviisist. Ta arutleb: Lätis elades on mustlased paratamatult võtnud lätlastelt üle mitte ainult traditsioonid (näiteks pulmakombed), vaid ka elulaadi. Identiteedi muutumise ja sellega seotud lahkarvamuste näiteks võib tuua Austra ja Ziedonise kahekõne küttepuude saamisest:

Austra: Varem: kui mustlastel polnud piisavalt puid kuuris, läksid nad vargile või võtsid lahti mõne pingi või tara ja... kui nägid lauajuppi vedelemas, tassisid selle koju... või mõne vana mööblitüki, mis oli ära visatud, lõhkusid küttepuudeks, tassisid koju - näe, ongi küte. Aga nüüd: mustlane on kui lätlane, kui tuleb ilus selge ilm, nii kohe läheb puid tegema, lõhub, kraamib... peaaegu nagu lätlane.

Ziedonis: Aga nii peabki olema... Sa pead ajaga sammu pidama, pole midagi parata. (NMV-4071.)

Teises mustlasperes võib olla just naine see, kes ajaga sammu pidamist õigeks peab. Näiteks püüab ta tütreid koolitada; lubab neil kanda riideid, mis muidu 
Ziedonis Leimanis. Ieva Garda-Rozenberga foto, Kuldīga 2013.

oleksid mustlasnaistele sobimatud (püksid, lühike kleit). Otsuste tegemisel peres jäävat viimane sõna siiski mehele, nagu on mehe teha ka valik, kas minna lahku või leppida.

Brigita Zavicka esitatu on hea näide identiteedikonflikti uurimiseks. Vastuolud ja mõtisklused läbivad kogu tema jutustust ja sageli on neid näha isegi samas

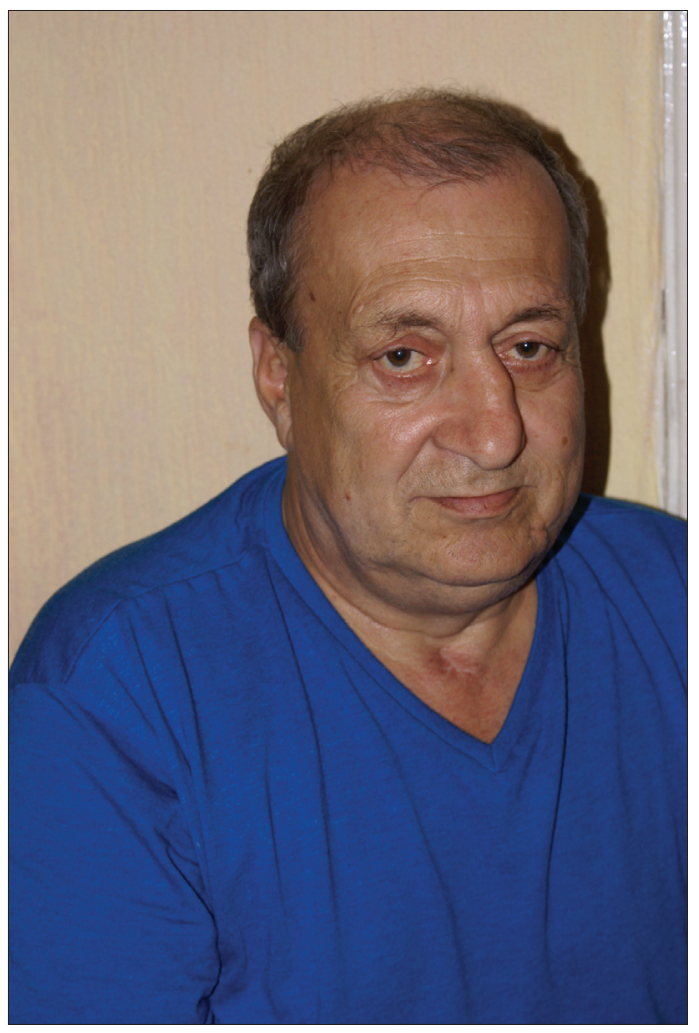
lauses:

Palju on elus korda läinud ja palju on sellist, mis siiski korda läinud ei ole. Pole enam neid mustlaste tavasid, näe, ei tule kaasa kõik see, millest vanasti pidi rangelt kinni pidama. Minu lapselapsed selliseid asju ei teagi, kuna nende ema seda enam ei ópetagi, et seda pole vaja. (NMV-4073.)

Nii jutustab ta intervjuu alguses endast mustlase vaatepunktist, intervjuu lõpus aga jõuab ta järeldusele, et ta ei sarnane üldse teiste mustlastega, sest on lätistunud. Seda tugevdab ka võorrandumise tunne, sest selliseid mustlasi, kes "ajaga sammu peaksid", olevat väga vähe. Nii ütleb ta end tundvat oma vaadetes üksildasena. Sisemist ebaselgust on osalt näha ka Ziedonis Leimanise loos. Ühelt poolt mainib ta intervjuus korduvalt, et mustlane peab "ajaga sammu pidama" ja et mustlased sarnanevad üha enam lätlastega ning et "see peabki nii olema". Kuid teiselt poolt ei taha ta kaotada oma mustlase-mina. Tema mõtisklusi katkestab abikaasa Austra, öeldes otsustavalt: "Mustlane jääb mustlaseks, lätlane jääb lätlaseks." Viivitamatult tehakse siis kokkuvõte, millest selgub, et kunagi olnu (eluviis, tavad, kõlblus, tõekspidamised) on tänapäeval taandunud, ainult keel on veel jäänud. Näiteks kõrghariduse omandanud õetütart iseloo- 


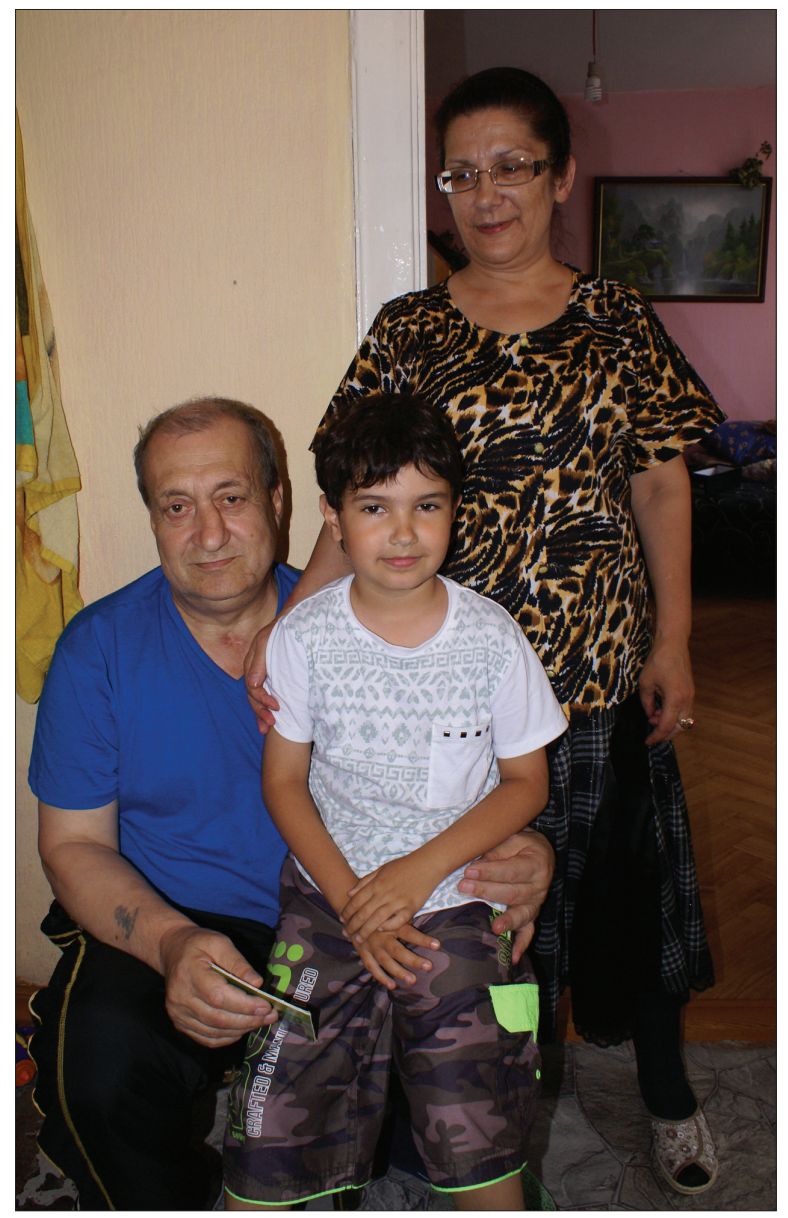

Leimaniste pere. Ieva GardaRozenberga foto, Kuldīga 2013.

mustades ütleb Austra Leimane: "Mustlaskeelt räägib, aga rohkem midagi tast pole kui mustlasest. Rohkem lätlane kui mustlane."

Austra Leimane ja Brigita Zavicka, eriti Ausma Leimane kõneldu viitab sellele, et mustlased tajuvad end olevat kahe kultuuri vahel, suutmata õieti otsustada, kuhu suunduda või kuidas edasi toimida. Kuid hoolimata lugudes esinevatest kõhklustest kultuuriliste ja elustiililiste valikute suhtes on need kõhklused esitatud läbimõeldult, varem välja kujundatud arusaamadele tuginedes. Seda võib täheldada mitte ainult kõnesole-

vate sündmuste kujutamisel, vaid ka oma kultuuri kajastamisel. Eeltoodud mustlasnaiste elulood võiksid ühtlasi olla mustlaste kogukonna kultuuriesitused lätlastest intervjueerijatele, sest need põhinevad mustlasrahva ajalool, nähtuna nende endi vaatepunktist, viitavad mustlaste saatusele ja suhetele lätlaste ja läti kultuuriga.

\section{Kokkuvõtteks: elulood kultuuriesitusena}

Nii liivlaste kui ka mustlastega tehtud intervjuud sisaldavad mälestusi, mida on korratud mitmetes variatsioonides ja mis igas esituses taas põimuvad. Lugude teemavalik, ülesehitus, väljendusviis ja keelekasutus kannavad teavet kultuurist ja ühiskonnast, milles jutustaja on elanud. Elusündmuste esitus jutustuses 
loob kultuuriteksti, mis lubab vaadelda ajaloolist, sotsiaalset ja kultuurilist kogemust teisest vaatevinklist mitte ainult uurijatel, vaid ka jutustajatel endil. Kuidas toimida, kui intervjueerija ja jutustaja esindavad eri kultuure? Kuidas läheneda teisele ja mõista teise kultuuri? Elulugude jutustamine ja kuulamine on oluline samm teel teise tundmaõppimisele - elulood, mis toovad kuulaja jutustaja maailma, lubavad näha nii ühist kui erinevat ja teistsugust. Seejuures mitte ainult teistsugust, vaid ka näha teise pilguga pealtnäha tuntut - oma pereliikmeid, naabreid, oma kodulinna elanikke.

Intervjuudes esile tulnud etnilise kultuuri erijoontele lisavad tähenduslikkust dünaamilised protsessid ühiskonnas, mis tasandavad või kustutavad kas siis liivipäraseid või vastavalt mustlaslikke kultuurijooni. Muutuste käigus sulanduvad need kultuurilised kogukonnad üldisesse ühiskonnapilti. Eluloointervjuud ja nende analüüs võimaldavad süüvida erinevate rahvarühmade tavapärastesse ettekujutustesse ja kultuurimudelitesse, lubades neid suhestada nii oma rühma kui ka Läti kollektiivse mäluga üldiselt. Siin analüüsitud kahe rahvarühma eluloointervjuude vaatlus võimaldas neid üksikuid-eripäraseid kultuure lõimida üldisemasse rahvuslikku ajaloo- ja kultuuripilti.

\section{Kommentaarid}

1 Artikkel on seotud Läti Teadusnõukogu rahastatud projektiga "Etniline ja narratiivne mitmekesisus eluloo-konstruktsioonides Lätis”, 2013-2014. Autorid tänavad Rūta Karmat artikli lätikeelse käsikirja tõlkimise eest eesti keelde ja Amanda M. Jātniecet ingliskeelse kokkuvõtte tõlkimise eest.

${ }^{2}$ Arhiiv on kujunenud pärimusliku ajaloo ja elulugude uurimise käigus ning asub Läti Ülikooli filosoofia ja sotsioloogia instituudis.

3 Toimetaja märkus: vrd Oskar Loorits, Liivi rahva usund IV. Tartu: EKM rahvausundi ja meedia töörühm 2000, lk 69 (http://www.folklore.ee/rl/pubte/ee/lru//ru4/lru4_3.pdf -5 . veebruar 2014).

${ }^{4}$ Hinrich Lose andis 1941. aasta 4. detsembril välja korralduse kõrgematele SS ja politsei juhtidele Ostlandis, nõudes, et mustlastega toimitaks samal viisil nagu juutidega. 1942. aasta 14. jaanuaril anti välja veel üks, eelmisest rangem korraldus - arreteerida kõik ümbruskonnas olevad mustlased, välja arvatud need, kellel on korralik töö ja kes ei ole ühiskonnale poliitiliselt või kriminaalselt ohtlikud. 1943. aasta 15. novembril anti välja järjekordne korraldus võrdsustada kõik ringirändavad mustlased ja nn segaverelised juutidega ning paigutada nad koonduslaagritesse (Vestermanis 1993).

5 Sarnasest juhtumist räägib ka Kārlis Rudevičs episoodis, milles ta kirjeldab sõjaväkke võetud õemehe hukkumist: mustlasi, keda ei iseloomusta kavalus ja leidlikkus ja kes läksid näiteks vabatahtlikult armeesse, nimetab Rudevičs lihtsameelseteks. 


\section{Arhiiviallikad}

NMV (Nacionālās mustvārdu vēsture) - Rahvuslik Suulise (Pärimusliku) Ajaloo Arhiiv. Läti ülikool, filosoofia- ja sotsioloogiainstituut, Riia.

NMV-2. Alvīne Mūrniece, s 1906, Lūžņā, intervjueerinud Māra Zirnīte, 1987, Lūžņā.

NMV-3. Lizete Švanenberga, s 1902, Lūžņā, intervjueerinud Māra Zirnīte, 1987, Lūžņā.

NMV-19. Emīlija Rulle, s 1910, intervjueerinud Māra Zirnīte, 1989,Ventspils.

NMV-86. Paulīne Kḷaviṇa, s 1918, Vaidē, intervjueerinud Māra Zirnīte, 1998, Vaidē.

NMV-234. Jānis Neilands, s 1918, Venemaa, intervjueerinud Māra Zirnīte, 1994, Ventspils.

NMV-300. Jānis Ērenštreits, s 1942, Valdis Dambergs, Sīragā, intervjueerinud Māra Zirnīte, 1998, Mazirbē.

NMV-1635. Ženija Belte, s 1932, Lūžņā, intervjueerinud Biruta Stone, 2002, Ugālē.

NMV-1660. Lūcija Stepane, s 1925, Talsi, intervjueerinud Lita Vēkaise ja Ieva Tihovska, 2002, Ventspils.

NMV-1661. Olga Burkevica, s 1928, Rēzekne, intervjueerinud Lita Vēkaise, Ilze Akerberga ja Ieva Tihovska, 2002, Ventspils.

NMV-1662. Valija Pauča, s 1936, Vārme vald, intervjueerinud Lita Vēkaise ja Ieva Tihovska, 2002, Ventspils.

NMV-2108. Kārlis Rudevičs, s 1939, Vangaži, intervjueerinud Rasa Strautmane, 2000, Saulkrasti.

NMV- 2634. Aina Bolšinga, s 1938, Dūmelē, intervjueerinud Māra Zirnīte, 1994, Kolkā.

NMV-4070. Ausma Leimane, s 1958, Kuldīga, intervjueerinud Kaspars Zellis ja Edmunds Šūpulis, 2013, Kuldīga.

NMV-4071. Ziedonis Leimanis, s 1952, Austra Leimane, Kuldīga, intervjueerinud Kaspars Zellis ja Edmunds Šūpulis, 2013, Kuldīga.

NMV-4073. Brigita Zavicka, s 1959, Kuldīga, intervjueerinud Ieva Garda-Rozenberga, 2013, Kuldīga.

NMV-4078. Zelma Ignāte, s 1956, Talsi, intervjueerinud Māra Zirnīte, 2013, Talsi.

\section{Kasutatud kirjandus}

Bahtin, Mihhail 1986 = Bakhtin, Mikhail 1986. Speech Genres and Other Late Essays. Austin: University of Texas Press.

Bauman, Richard 1986. Story, Performance and Event: Contextual studies of oral narrative. Cambridge Studies in Oral and Literate Culture 10. New York: Cambridge University Press. 
Bauman, Richard 2004. A World of Others' Words: Cross-Cultural Perspectives on Intertextuality. Malden-Oxford: Blackwell Publishing.

Bauman, Richard \& Briggs, Charles L. 1990. Poetics and Performance as Critical Perspectives on Language and Social Life. Annual Review Anthropology 19, lk 59-88.

Bela-Krūmiṇa, Bela 2002. Dzīvesstāsti mutvārdu vēstures skatījumā [Elulood pärimusliku ajalooo vaatepunktist]. Lūse, Agita (toim). Cilvēks. Dzīve. Stāstījums [Inimene. Elu. Jutustus]. Riia: Latvijas Antropologu biedrība, Latvijas Universitātes Literatūras, folkloras un mākslas institūts, lk 30-36.

Bruner, Edward M. 1986. Experience and its Expressions. Turner, Victor W. \& Bruner, Edward M. (toim). The Anthropology of Experience. United States of America: University of Illinois Press, lk 3-32.

Gilman, Lisa 2009. Genre, Agency, and Meaning in the Analysis of Complex Performances: The Case of a Malawian Political Rally. Journal of American Folklore 122 (485), lk 335-362.

Goffman, Erving 1959. Presentation of Self in Everyday Life. New York: Ancor Books.

Krūmiṇa, M. 2012. Mutvārdu vēstures avotu perspektīva vēstures izpētē [Pärimusliku ajaloo perspektiiv ajaloo uurimises]. Garda-Rozenberga, Ieva (toim). Dzīvesstāsts un pašapziņa. Mutvārdu vēsture Latvijā [Elulugu ja eneseteadvus. Pärimuslik ajalugu Lätis]. Riia: LU Filozofijas un socioloǵijas institūts, lk 21-31.

Malkki, Liisa 1992. National Geographic: The Rooting of Peoples and the Territorialization of National Identity among Scholars and Refugees. Cultural Anthropology 7 (1), lk 24-44 (doi: 10.1525/can.1992.7.1.02a00030).

Myerhoff, Barbara 1980. Number Our Days: A Triumph of Continuity and Culture Among Jewish Old People in an Urban Ghetto. New York: A Touchstone Book.

Riessman, Catherine Kohler 1993. Narrative Analysis. Qualitative Research Methods Series 30. Newbury Park (California): SAGE Publications, Inc.

Skultans, Vieda 1998. The Testimony of Lives. London \& New York: Routledge.

Vestermanis, Marg’ers 1993. Čigānu genocīds vācu okupētajā Latvijā (1941-1945) [Mustlaste genotsiid Saksa armee poolt okupeeritud Lätis]. Latvijas Vēsture [Läti ajalugu] 4 (11), lk 37-40.

Zirnīte, Māra 2011. Lībieši Ziemel̦kurzemes ainavā. [Liivlaste maastik Põhja-Kuramaal]. Riia: Dabas aizsardzības pārvalde (http://www.daba.gov.lv/upload/File/Publikacijas/ GR_LibieshiZKA.pdf - 4. veebruar 2014). 


\title{
Summary
}

\section{Life stories in ethnic culture research: Livonian and Roma life stories in Latvia}

\author{
Ieva Garda-Rozenberga, Māra Zirnīte
}

Keywords: ethnic culture, life stories, Livonian, oral history, Roma

Even though narrating is a universal phenomenon, there is no one universal narration model, much less a universal life story model. This is also verified by the life stories from various ethnic groups that have long lived among Latvians in the Latvian cultural space.

Life stories play an important role in the research of ethnic history and social memory, because both Roma and Livonian cultures and their transmission between generations have traditionally been based on the oral tradition. Any attempt to reconstruct the history of these two ethnic groups is therefore encumbered as well as open to various interpretations. Life stories can likewise be interpreted in different ways. This article examines the creation of life stories both as a social event in a specific time and space and as one of the forms of cultural experience.

The article presents excerpts from Livonian and Roma life stories, thereby revealing not only what is unique about each narrator, but also providing an insight into a certain group's experience of reality that is expressed through narratives. The type of expression and use of language, story composition, intertextuality and presentation all contain information about the culture and society in which the narrator lives.

Audio recordings from the National Oral History Archives at the Institute of Philosophy and Sociology of the University of Latvia have been used for this study. Over the 20 years since its founding, the archives have amassed a voluminous Livonian oral history collection. The interviews took place in the Latvian language, in the local tammnieku dialect spoken by the Livonians who were born and have grown up along the northern Kurzeme coast. The Roma interviews were also recorded in Kurzeme, some in the 1990s, but most just this past summer, within the project "Ethnic and Narrative Diversity in the Construction of Life Stories in Latvia", financed by the Latvian Council of Science.

Life stories are unique performances, but they are, at the same time, also created within a complicated, established social situation and are influenced by several aspects: the interview context, cooperation between the narrator and the interviewee as two separate personalities, the narrator's abilities and individual creativity.

Cultural and historical conditions have influenced both Livonian and Roma life stories, thereby revealing influences from their usual environment, traditional way of life and folklore, as well as from Latvian culture and the era in which they live. 